\title{
PROF. DR HAB. JERZY WOJTCZAK-SZYSZKOWSKI: CURRICULUM VITAE
}

Jerzy Wojtczak-Szyszkowski, urodzony w Warszawie 2 października 1939 r., absolwent ówczesnego Wydziału Filologicznego Uniwersytetu Warszawskiego, doktor habilitowany nauk humanistycznych, emerytowany profesor zwyczajny Uniwersytetu Warszawskiego, przez trzy kadencje pełnił funkcję Kierownika Zakładu Języków i Literatur Antycznych Instytutu Filologii Klasycznej Uniwersytetu Warszawskiego, absolwent Wydziału Filozofii Chrześcijańskiej ówczesnej Akademii Teologii Katolickiej, Kawaler Papieskiego Orderu Świętego Grzegorza, Wielki Oficjał Zakonu Rycerskiego Grobu Bożego w Jerozolimie.

Studium filologii klasycznej poszerzył o badania nad pismami Ojców Kościoła i hagiografią polskiego średniowiecza oraz kulturą tego okresu, problematyką niezwykle ważną dla promocji kultury chrześcijańskiej w naszym kraju, zwracając uwagę na szerzący się kult Matki Bożej już u zarania chrześcijaństwa w Polsce. Owocem tego są m.in. przekłady i studia filologiczne nad życiorysami św. Kingi i św. Stanisława Biskupa i Męczennika, publikowane jako książki i w innej formie.

Szczególnie bliska mu jest problematyka związana z kulturą polską, dlatego stara się szerzyć wiedzę na temat kultury polskiego średniowiecza w swoich wykładach i piśmiennictwie. Kultura ta bowiem, mająca swoje korzenie w kulturze łacińskiej, pozostaje w bezpośrednim związku z kulturą europejską w jej najlepszej postaci.

Oryginalne teksty napisane $\mathrm{w}$ języku łacińskim przez Jerzego Wojtczaka-Szyszkowskiego oraz thumaczone przez niego na łacinę obejmują blisko 4000 stron, wśród nich na pierwsze miejsce wysuwają się liczne dokumenty i akta związane z procesami beatyfikacyjnymi polskich kandydatów na ołtarze (m.in. był w ścisłym gronie tłumaczy procesu beatyfikacyjnego obecnie już kanonizowanego Arcybiskupa Zygmunta Szczęsnego Felińskiego, Ojca Maksymiliana Marii Kolbego, Błogosławionego Ojca Honorata Koźmińskiego, Błogosławionej Matki Marii Karłowskiej, Błogosławionej Sancji Szymkowiak, Błogosławionej Matki Marii Darowskiej, oraz tłumaczem dokumentów sądowych i innych tekstów). Odznaczony honorowym dyplomem na Certamen Capitolinum, autor ponad 120 prac naukowych i popularno-naukowych różnej objętości, autor podręczników do nauki łaciny, promotor wielu prac magisterskich, 8 prac doktorskich, autor licznych recenzji doktorskich, habilitacyjnych i dorobku osób ubiegających się o tytuł naukowy profesora.

Twórca wielu przekładów również na język polski, m.in. dokumentu związanego z ustanowieniem Orderu Niepokalanego Poczęcia Najświętszej Maryi 
Panny przez Papieża Urbana VIII, będącego prawzorem obecnego Orderu Rycerstwa Jasnogórskiej Bogarodzicy.

Jego praca związana z recepcją jednego z najważniejszych dokumentów średniowiecznej kanonistyki przedgracjańskiej przez polskie prawo cywilne tamtego okresu, mianowicie szesnastego rozdziału Dekretu Iwona z Chartres, do której dołączony został dokonany przez niego pierwszy polski przekład tekstu owego dokumentu, ma istotne znaczenie dla wskazania wpływu kanonistyki przedgracjańskiej na polskie prawo cywilne i zwyczajowe w okresie przed ustawodawstwem Kazimierza Wielkiego. W roku 2014 ukazał się przekład i opracowanie trzech rozdziałów słynnego dzieła jednego z najwybitniejszych kanonistów średniowiecza, Burchardta z Wormacji, pod kątem wyjaśnienia stanowiska Kościoła w okresie poprzedzającym spór o inwestyturę.

Członek Association Internationale des Etudes Patristiques, nadto Sekcji Patrystycznej dawniej funkcjonującej przy Komisji do Spraw Nauki Episkopatu Polski, Komisji Badań nad Antykiem Chrześcijańskim Towarzystwa Naukowego KUL, Członek Zwyczajny Warszawskiego Towarzystwa Naukowego, Polskiego Towarzystwa Filologicznego, Członek honorowy Komitetu Katyńskiego.

W swojej działalności pedagogicznej i naukowej koncentruje się na promocji kultury i doktryny chrześcijańskiej w naszym społeczeństwie, gromadząc również wokół siebie osoby, którym ta kultura jest bliska.

Jego wykłady na różnych uczelniach cieszą się dużą popularnością i gromadzą licznych słuchaczy, którzy w ten sposób przyswajają sobie wiedze o kulturze chrześcijańskiej naszego narodu w dawnych wiekach, a przez to zyskują impuls do naśladowania wielkich świętych i wybitnych postaci w naszych dziejach. W ostatnich latach zajmuje się również prezentacją tych postaci w środowiskach polonijnych za granicą.

Autor wydanego w 2004 roku zbioru poezji łacińskiej, wydany w roku 2011 zbiór drugi był prezentowany w środowisku naukowym i artystycznym Warszawy 20 października ubiegłego roku. W jednym i drugim zbiorze znajdują się m.in. utwory poświęcone kultowi Matki Bożej Jasnogórskiej. Utwór „Luctus Mariae” znajdujący się w tym zbiorze, do którego napisał muzykę warszawski kompozytor Paweł Łukaszewski, został wykonany w czasie festiwalu pasyjnego „Crucifixus est” w roku 2012. Do innych łacińskich tekstów poetyckich jego pióra zostały napisane liczne utwory przez współczesnych kompozytorów polskich, m.in. na jednym z Festiwali Muzyki Sakralnej w Częstochowie „Gaude Mater Polonia” wykonany został utwór o Jasnogórskiej Bogarodzicy. Istnieje szereg edycji fonograficznych tych utworów, m.in. w roku 2015 ukazała się płyta zawierająca utwory muzyczne skomponowane do napisanych przez niego łacińskich tekstów, obok kompozycji napisanych do tekstów papieża św. Jana Pawła II.

Przez trzynaście lat pełnił funkcję Zwierzchnika Polskiego Zakonu Rycerskiego Grobu Bożego w Jerozolimie, od momentu zaistnienia Zwierzchnictwa i powierzenia mu tej funkcji zabiegał i nadal zabiega o promocję Zakonu na 
terenie kraju i dobre imię Zwierzchnictwa w całym Zakonie. W wywiadach prasowych, wystapieniach telewizyjnych i radiowych zapoznaje społeczeństwo katolickie w Polsce z celami i funkcją Zakonu we współczesnym świecie, nawiązując do jego historii i tradycji, ukazuje doniosłość jego roli i znaczenie działalności jego członków dla podtrzymania obecności Kościoła katolickiego i chrześcijan w Ziemi Świętej.

Znajomość problematyki kościelnej i języka Kościoła, którą posiada prof. J. Wojtczak-Szyszkowski, pomaga mu w rozwiązywaniu wielu problemów różnej natury. Ofiarowuje swój czas, pracę i umiejętności również dla sprawy elitarnego, zatwierdzonego przez papieża św. Jana Pawła II, Rycerstwa Jasnogórskiej Bogarodzicy, w którym działa już od dwudziestu lat. Jako Komandor Rycerstwa Jasnogórskiej Bogarodzicy zabiega o szerzenie kultu Matki Bożej i rodzimych Swiętych w środowisku akademickim i naukowym w Polsce. Dzięki Jego działalności idee rycerskie znajdują coraz większy rezonans wśród społeczności katolickiej w Polsce.

ks. Piotr Szczur 
